\title{
Structural changes in an aquatic microbial food web caused by inorganic nutrient addition
}

\author{
Kristina Samuelsson ${ }^{1,2,}{ }^{*}$, Johnny Berglund ${ }^{1,2}$, Pia Haecky ${ }^{2,3}$, Agneta Andersson ${ }^{1,2}$ \\ ${ }^{1}$ Marine Ecology, Dept. of Ecology and Environmental Science, Umeå University, 90187 Umeå, Sweden \\ ${ }^{2}$ Umeå Marine Sciences Centre, Norrbyn, 91020 Hörnefors, Sweden \\ ${ }^{3}$ Marine Biological Laboratory, University of Copenhagen, Strandpromenaden 4, 3000 Helsingör, Denmark
}

\begin{abstract}
Present theories regarding nutrient status of aquatic systems and plankton size structure, food web length and nutritional modes were tested in a microcosm experiment using water from the northern Baltic Sea. The different trophic levels included were those of pico-, nano- and microplankton, representing bacteria, flagellates, ciliates and diatoms. Nutrient enrichment resulted in a higher biomass and changed size-structure of the organisms. The nutrient-enriched microcosms changed from a picoplankton-dominated system to a microplankton-dominated system. In contrast, the nutrient-poor treatment remained at the pico- and nanoplankton levels. The increase in biomass within the enriched treatment resulted in a lengthening of the food chain to include a firmly established ciliate community. In accordance to this, no shift to inedible or toxic species was observed. In the nutrient-poor treatment the ciliates were kept at very low population densities. Furthermore, a potentially mixotrophic flagellate (Chrysochromulina sp.) was able to maintain a positive population growth in the nutrient-poor treatment, while specialised heterotrophic or autotrophic flagellates (Paraphysomonas imperforata Lucas and Plagioselmis prolonga Butcher) decreased in numbers. In the nutrient enriched system the potential mixotrophic flagellate coexisted with specialised heterotrophic and autotrophic forms. A clear succession pattern of diatoms was observed, illustrating early and late successional species within diatom populations.
\end{abstract}

KEY WORDS: Bacteria - Flagellates · Ciliates · Phytoplankton · Mixotrophy · Food web length · Nutrient status Resale or republication not permitted without written consent of the publisher

\section{INTRODUCTION}

In pelagic systems, the concentration of nutrients and the process of nutrient cycling greatly influence the dynamic and structure of the food web (Legendre \& Rassoulzadegan 1995). Thingstad \& Sakshaug (1990) suggested that an increased nutrient load leads to a change from dominance of small cells, like heterotrophic bacteria and cyanobacteria in nutrient-poor aquatic environments, to dominance of larger plankton in nutrient-rich environments. Nutrient enrichment would further lead to a lengthening of the food chain, due to the higher carrying capacity of the system.

*E-mail: kristina.samuelsson@eg.umu.se
According to this theory a new trophic level establishes when the food supply is sufficient for its growth rate to balance its loss rate. This theory further assumes a linearly formed food web in which the top level and every second trophic level beneath it will acquire a higher biomass if the nutrient status of the water increases. It may be hypothesised that if the microbial food web would be less strict regarding size classes and, for example, was dominated by omnivorous organisms, such clear shifts in biomasses and trophic levels with increasing nutrient enrichment would not occur. One example of omnivorous organisms is the ciliates, which are an important functional group in the microbial food web. Ciliates have been shown to feed on prey of different sizes ranging from bacteria to prey of their own size (Gifford 1985). 
Another factor that might hinder a lengthening of the food chain with increasing nutrient loading is that predation-resistant species can be favoured as a response to strong predation pressure (Jürgens \& Montserrat Sala 2000). This can result in resource-controlled population dynamics (Vanni 1987, Balciunas \& Lawler 1995, Brett \& Goldman 1997).

The food webs in natural systems are more complicated than simple theoretical models, which only include autotrophic and heterotrophic species. Mixotrophy among protists of different taxonomic groups has been shown to be common in marine, brackish and freshwater environments (e.g. Sanders 1991). An advantage of being a mixotroph compared to a specialist autotroph or heterotroph is assumed to be better survival during periods of resource limitation (e.g. Andersson et al. 1989, Nygaard \& Tobiesen 1993). During these situations, mixotrophs are superior to autotrophs due to their ability to retrieve phosphorus and nitrogen through phagotrophy, and superior to heterotrophs due to their photosynthetic capacity (Nygaard \& Tobiesen 1993). Although this theory is well established, there are only a few competition experiments published on heterotrophic, mixotrophic and autotrophic flagellates. These studies include a mixotrophic chrysophyte (Ochromonas sp., Rothhaupt 1996), mixotrophic dinoflagellates (Havskum \& Hansen 1997) and unidentified mixotrophic species (Baretta-Bekker et al. 1998, Christaki et al. 1999). None is presented on mixotrophic prymnesiophyceans, which is an important taxonomic group in marine and brackish water systems, like for example the Baltic Sea (Andersson et al. 1996, Hajdu et al. 1996). It can thus be concluded that the theory regarding the mechanisms governing the structure of the flagellate community in different types of aquatic systems has not yet been fully validated in experimental systems.

The aim of this study was to test the paradigms and food web theories outlined above, by performing a nutrient enrichment experiment using seawater from the northern Baltic Sea. We were especially interested in studying 2 aspects of food webs: (1) Does natural seawater contain potentially toxic or inedible species of phytoplankton, bacteria or flagellates that hinder a lengthening of the microbial food chain with nutrient enrichment? If such species were promoted due to nutrient loading, then no positive growth response of the top predators (ciliates) would be observed. In an earlier study, using isolated planktonic microorganisms, it was indeed found that increased productivity caused a lengthening of the food microbial chain (Kaunzinger \& Morin 1998). However, in natural aquatic systems the situation may be different due to the presence of toxic or inedible species. (2) The other aspect was to study the competitive advantage of a potentially mixotrophic prymnesiophycean, Chrysochromulina sp. We hypothesised that this potentially mixotrophic flagellate would have a competitive advantage in the nutrientconstrained control, while specialised autotrophic and heterotrophic forms would dominate in the nutrientenriched treatment. To our knowledge this is the first competition experiment including a potentially mixotrophic prymnesiophycean and specialised autotrophic and heterotrophic flagellates.

\section{MATERIALS AND METHODS}

Growth medium. Coastal seawater from the northern Baltic Sea (633' 26" N, 1950' 14" E) was used as growth medium. The seawater was collected at $10 \mathrm{~m}$ depth in January 2001 from the brackish water inlet system at the Umeå Marine Sciences Centre. At the sampling time, seawater was covered by ice, the temperature was $0^{\circ} \mathrm{C}$ and the salinity $4.5 \%$. The water was filtered through a $100 \mu \mathrm{m}$ nylon net to exclude mesozooplankton and larger detritus particles. To reduce the inorganic nutrient concentration, the seawater was pre-grown in polycarbonate bottles at $10^{\circ} \mathrm{C}$ for $2 \mathrm{wk}$ using a diel period of $12 \mathrm{~h}$ light $\left(\sim 100 \mu \mathrm{mol}\right.$ quanta $\mathrm{m}^{-2}$ $\mathrm{s}^{-1}$ ) and $12 \mathrm{~h}$ darkness. After that the seawater was filtered through a $0.2 \mu \mathrm{m}$ poresize, $142 \mathrm{~mm}$ ø, polycarbonate filter (Schleicher \& Schuell).

Time course experiment. The time course experiment was performed in 6 polycarbonate bottles $(8 \mathrm{l})$, to which 61 growth medium and 21 seawater inoculum were added. The bottles were incubated over $40 \mathrm{~d}$ at $10^{\circ} \mathrm{C}$ with a diel period of $12 \mathrm{~h}$ light $(\sim 50 \mu \mathrm{mol}$ quanta $\mathrm{m}^{-2} \mathrm{~s}^{-1}$ ) and $12 \mathrm{~h}$ darkness. The day length used was in agreement with natural conditions, while the temperature was $\sim 5^{\circ} \mathrm{C}$ higher (Andersson et al. 1994). The seawater inoculum was collected from the brackish water inlet system at the Umeå Marine Sciences Centre. To 3 replicate bottles, $8 \mathrm{ml}$ of a nutrient stock solution were added twice a week (final concentration $2.0 \mu \mathrm{M}$ nitrate, $3.3 \mu \mathrm{M}$ ammonium and 1.6 $\mu \mathrm{M}$ phosphate). Addition of nutrient solution to the enriched bottles increased the volume by $1.2 \%$ and decreased the salinity from 4.5 to $4.45 \%$. The remaining 3 bottles served as nutrient-poor controls. To obtain similar changes in volume and salinity in the control as in the nutrientenriched treatment, $8 \mathrm{ml}$ distilled water were added to the control at the same frequency. Samples for analyses of prokaryotic and eukaryotic organisms were taken twice a week. Samples for analysis of prokaryotic organisms were preserved with formaldehyde (1.4\% final concentration), and samples for eukaryotic organisms were preserved with Lugol's solution $(0.2 \%$ final concentration). Before sampling, the bottles were turned upside-down 10 times to mix the water. 
Picoplankton. For analysis of autotrophic bacteria (cyanobacteria), 10 to $15 \mathrm{ml}$ of the formaldehyde-fixed samples were filtered onto $0.6 \mu \mathrm{m}$ poresize, $25 \mathrm{~mm} \varnothing$, polycarbonate filters (Poretics). After mounting on slides the samples were analysed in an epifluorescence microscope using green excitation light (510 to $560 \mathrm{~nm}$ ) and $1250 \times$ magnification. At least 200 cells per slide were counted. The cell sizes of the cyanobacteria were measured by using an ocular scale and the cell volumes calculated as spheres.

For analysis of heterotrophic bacteria, 2 to $5 \mathrm{ml}$ of the formaldehyde-fixed samples were filtered onto black $0.2 \mu \mathrm{m} 25 \mathrm{~mm}$ polycarbonate filters (Poretics). The filtered samples were then incubated with 10 drops of acridine orange for $5 \mathrm{~min}$. After mounting on slides the heterotrophic bacteria were counted in an epifluorescence microscope using blue excitation light (450 to $490 \mathrm{~nm}$ ) and $1250 \times$ magnification. At least 200 cells per slide were counted. Estimates of bacterial cell volumes were acquired by image analysis (Blackburn et al. 1998).

Nano- and microplankton. For flagellate, ciliate and autotrophic microplankton counts, 10 to $50 \mathrm{ml}$ of the Lugol-preserved samples were settled in Hydro-bios sedimentation chambers for $72 \mathrm{~h}$. Depending on the concentration of the different groups of microorganisms, different shares of the chamber bottom were scanned. Flagellate samples were counted at 400x magnification. Three types of flagellates were identified according to their morphology and colouration: autotrophic, mixotrophic and heterotrophic. The number of counted cells per flagellate type varied from 0 to 30 per sample. Autotrophic flagellates mainly consisted of the cryptophyte Plagioselmis prolonga Butcher. Potentially mixotrophic flagellates were dominated by the prymnesiophycean Chrysochromulina sp. For heterotrophic flagellates, the absence of chloroplasts was checked by epifluorescence microscopy. According to their morphology, at least $50 \%$ of the heterotrophic flagellates in the enriched treatments belonged to the Chrysophyceae. By using the transmission electron microscopy method described in Hajdu et al. (1996), we identified numerous scale plates from the heterotrophic crysophycean Paraphysomonas imperforata Lucas. The cell sizes were measured using an ocular scale and the biovolume calculated as a cone + sphere/ 2 for $P$. prolonga and as spheres for Chrysochromulina sp. and for heterotrophic flagellates.

Ciliates and autotrophic microplankton were counted at $200 \times$ magnification. The number of counted ciliate cells varied from 0 to 45 per sample. Ciliates were identified as Euplotes sp., Strobilidium/Lohmaniella spp., Strombidium spp. and cf. Uronema sp. Cell sizes were measured using an ocular scale and the biovolume of Euplotes sp. calculated as a rotational ellipsoid/2, Strobilidium/Lohmaniella spp. as a sphere, Strombidium spp. as a cone and Uronema sp. as a rotational ellipsoid. The autotrophic microplankton mainly consisted of diatoms and a green alga (Monoraphidium contortum [Thuret] Koma'rkova-Legenerova'). Among the diatoms Chaetoceros wighamii Brightwell, Skeletonema costatum (Greville) Cleve, Thalassiosira baltica (Grunow) Ostenfeld, Cylindrotheca closterium (Ehrenberg) Reimann \& J. Lewin and Fragilaria sp. were the most common species. The number of counted cells per taxonomic group varied from 0 to 1000 per sample. The cell sizes were measured using an ocular scale and the cell volume of $M$. contortum calculated as 2 cones, Chaetoceros spp. as ellipsoids, S. costatum and T. baltica as cylinders, C. closterium as parallelepipeds/2 and Fragilaria spp. as parallelepipeds.

Nutrient analysis. Samples for analysis of inorganic nutrients were taken at the beginning and end of the time course experiment. Double samples were taken at the start of the experiment and triplicate samples at the end of the experiment. The samples were filtered through $0.2 \mu \mathrm{m} 25 \mathrm{~mm}$ poresize ø, Gelman Supor-210 filters and frozen until analysis. Inorganic nutrient concentrations were measured using a TRAACS autoanalyser (Alfa Laval Bran Luebbe TRAACS 800) and standard seawater procedures (Grasshof et al. 1983). The standard errors for the phosphate, total phosphorus, ammonium, nitrate, total nitrogen and silicate analyses were on average $8,9,21,24,10$, and $30 \%$, respectively (data not shown).

Statistical analysis. Differences in the flagellate communities were tested by using a $t$-test. The average proportion of autotrophic, mixotrophic and heterotrophic flagellates was tested in the later part of the experiment, Days 25 to 39. During that period the plankton communities were relatively stable in both treatments. A significance level $(\alpha)$ of 0.05 was used.

\section{RESULTS}

In the nutrient-enriched incubations the plankton biovolume increased from $0.5 \mathrm{~mm}^{3} \mathrm{l}^{-1}$ at the start of the experiment to $19 \mathrm{~mm}^{3} \mathrm{l}^{-1}$ in the middle of the experiment (Fig. 1). During the second half of the experiment the total biovolume decreased to about half of the maximum value. In the nutrient-poor control the plankton biovolume remained low during the time course experiment, at $<1 \mathrm{~mm}^{3} \mathrm{l}^{-1}$. In both treatments the autotrophs dominated throughout the experiment, while the proportion of heterotrophs increased at the end of the experiment. At the beginning of the experiment approx. $50 \%$ of the total biovolume consisted of 


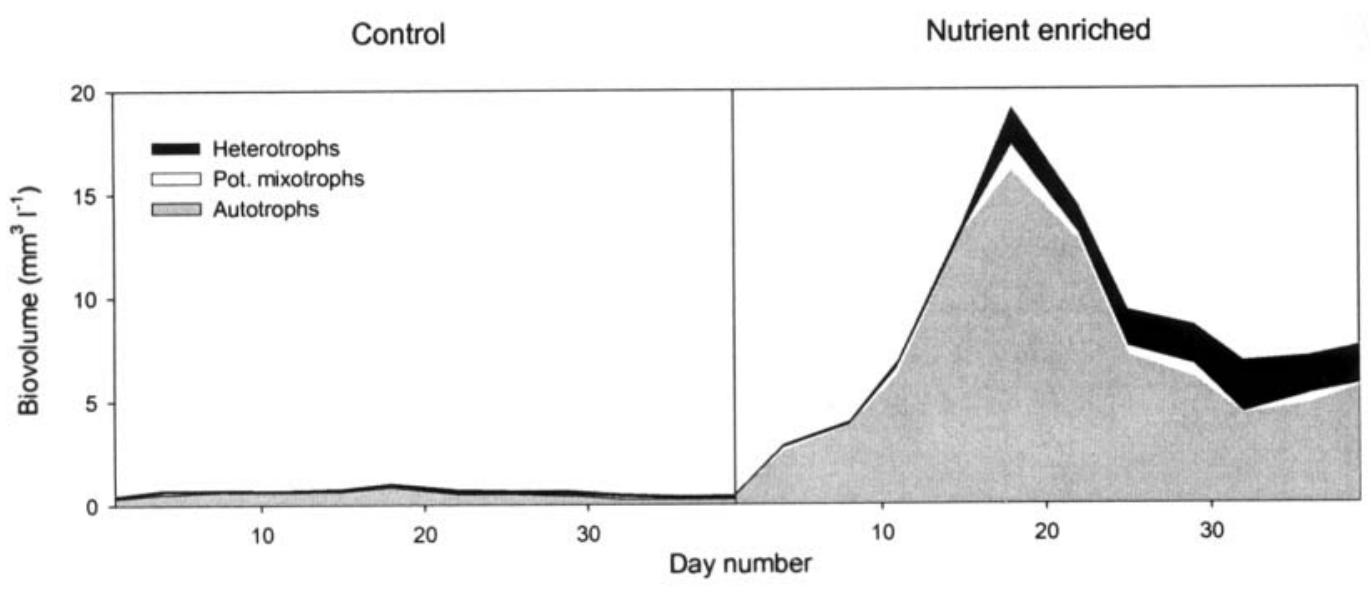

Fig. 1. Concentration of autotrophic, potentially mixotrophic and heterotrophic organisms throughout the time course experiment

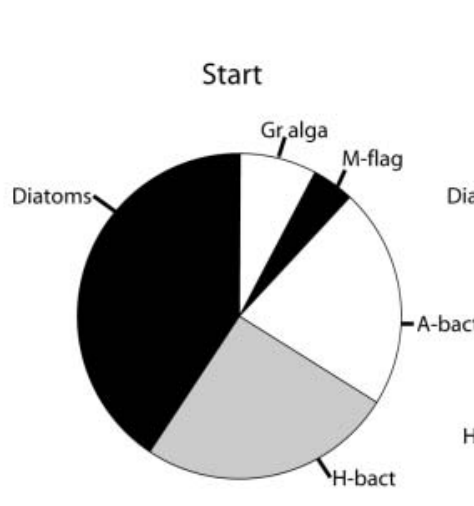

picoplankton (Fig. 2). The picoplankton fraction consisted of equal parts of heterotrophic and autotrophic bacteria. Microplankton (diatoms and a green alga) comprised the other dominant group, while nanoplankton (flagellates) only formed a smaller part $(<5 \%)$ of the biovolume. At the end of the experiment the plankton distribution had changed in both treatments. In the nutrient-poor control the nanoplankton fraction had increased to $\sim 20 \%$ of the biovolume, and the green alga disappeared. In the nutrient-enriched incubations, on the other hand, microplankton (diatoms and ciliates) dominated the plankton at the end of the experiment, constituting $84 \%$ of the biovolume. Nutrient enrichment, thus, promoted growth of relatively large microplankton, while nutrient limitation encouraged pico- and nanoplankton growth.

Predator-prey fluctuations were observed within the microbial food web in the nutrient-enriched systems. Shortly after the bacteria increased (Days 11 to 18), increases in the biovolume of heterotrophic flagellates and Chrysochromulina sp. were observed (Fig. 3). The increasing bacterial and flagellate concentrations were followed by an increase in the ciliate biovolume (Fig. 3). The ciliates subsequently consumed much of the flagellate biovolume during the second half of the experiment. Similar dynamics were also observed in
End Nutrient enriched

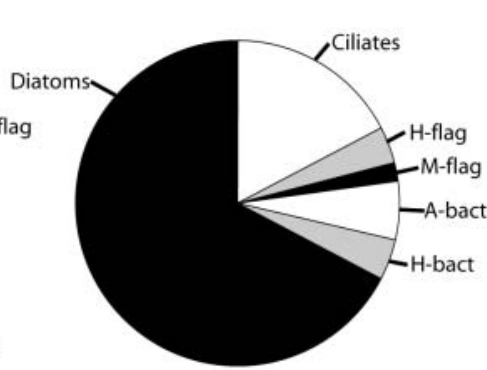

Fig. 2. Biovolume distribution of dominating organisms at the start and end of the experiment. H-bact $=$ heterotrophic bacteria, Abact = autotrophic bacteria, M-flag = potentially mixotrophic flagellate, $\mathrm{H}$-flag $=$ heterotrophic flagellates, $\mathrm{Gr}$ alga = green alga

the nutrient-constrained control incubations. The results of the control and enriched treatments, however, differed in 2 important aspects at the end of the experiment. Firstly, the flagellate community in the control was dominated by the potentially mixotrophic Chrysochromulina sp. (Fig. 4, Table 1). The proportion of Chrysochromulina sp. was significantly higher in the nutrient-poor controls (average 88\%) than in the nutrient-enriched treatment (average 33\%) (Table 1). Secondly, the ciliates became firmly established as predators on flagellates in the nutrient-enriched treatments, while in the control the ciliate numbers were close to or below the detection limit at the end of the experiment (Fig. 3). In the nutrient-enriched treatment an average of 65000 ciliates $1^{-1}$ were estimated at the end of the experiment (Days 32 to 39), while the average concentration in the control was 700 cells $1^{-1}$ over the same period. The ciliate numbers were below the detection limit $\left(<2200\right.$ cells $\left.\mathrm{l}^{-1}\right)$ in $70 \%$ of these control samples.

The bacterial cell volumes were measured during the last week of the experiment, when the plankton abundances were relatively stable. The median bacterial cell volumes were found to be similar in the nutrient-poor and nutrient-rich treatments, $0.07 \mathrm{\mu m}^{3}$ (Fig. 5). However, a group of relatively large bacteria 


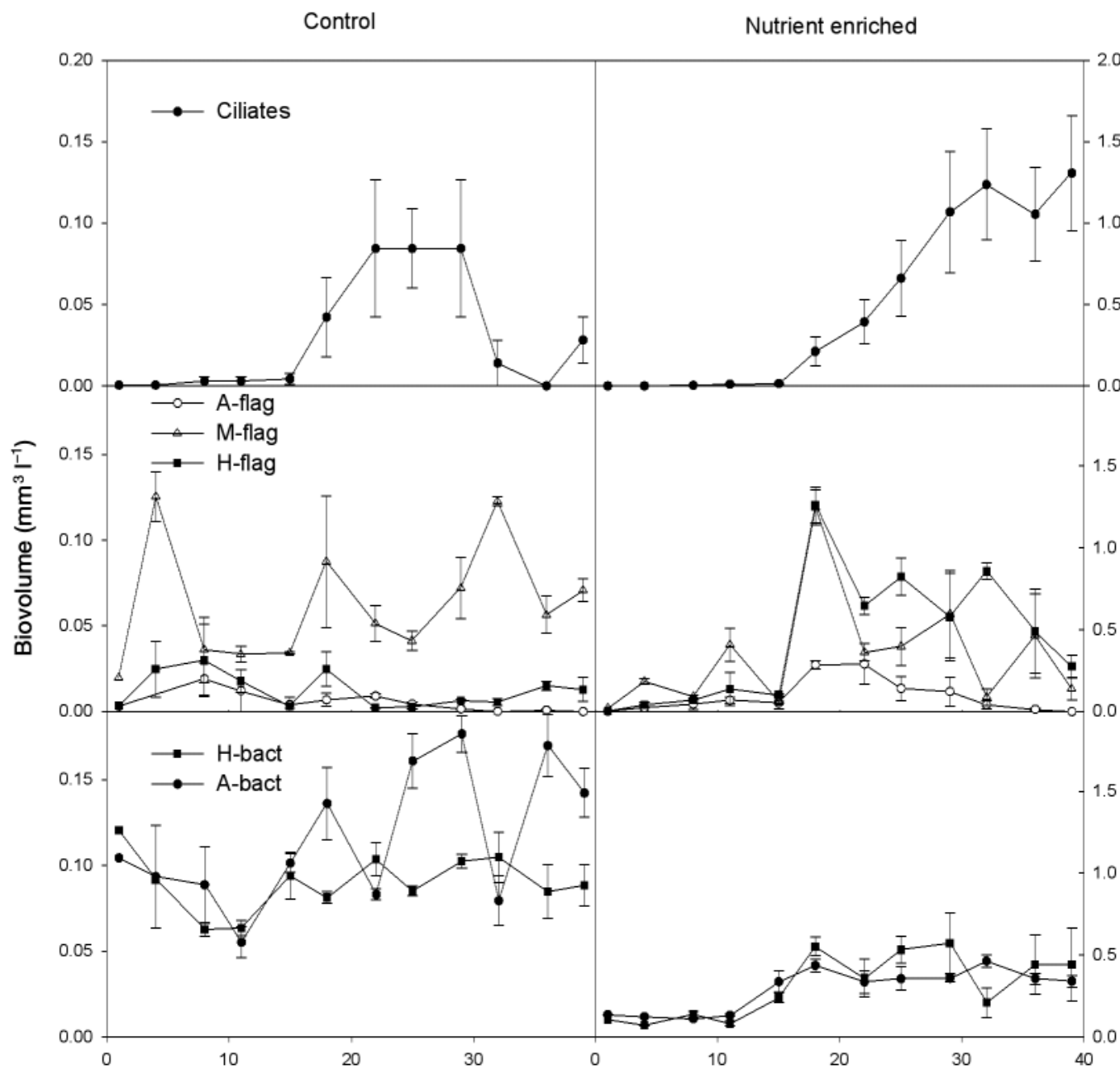

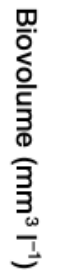

Fig. 3. Fluctuations in different trophic levels of the microbial food chain during the time course experiment. The different trophic levels were those of microplankton (ciliates, upper panel), nanoplankton (flagellates, middle panel) and picoplankton (bacteria, lower panel). $\mathrm{A}$ = autotrophic, $\mathrm{M}=$ potentially mixotrophic $\mathrm{H}=$ heterotrophic

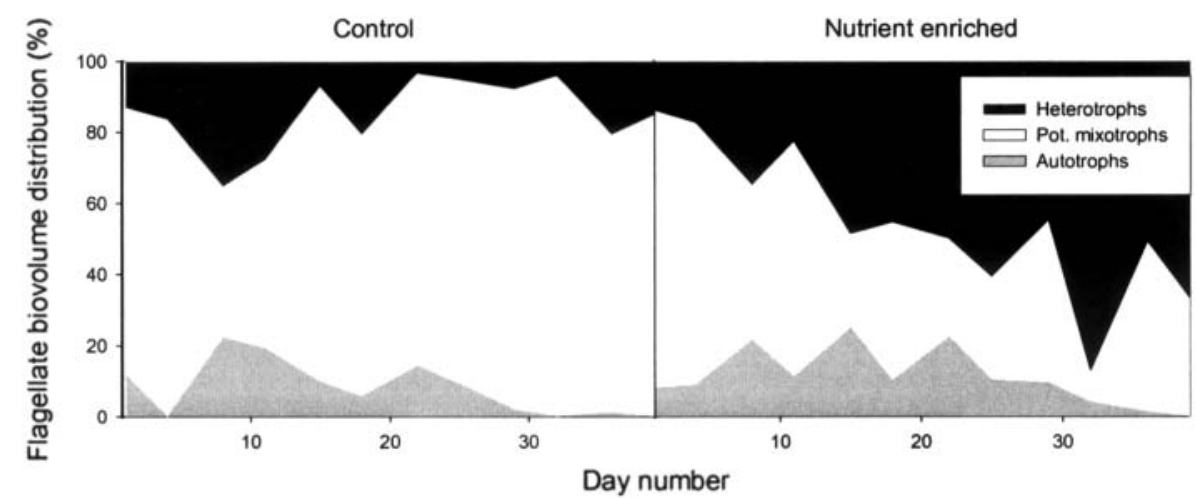

Fig. 4. Distribution of autotrophic, potentially mixotrophic and heterotrophic flagellates during the time course experiment

$\left(>0.2 \mu \mathrm{m}^{3}\right.$ ), with a median cell volume of $0.4 \mu \mathrm{m}^{3}$ (cell length 1.7 to $4.3 \mu \mathrm{m}$ ), were promoted in the nutrientrich treatment relative to the control. These cells constituted $36 \%$ of the biovolume in the control and $52 \%$ in the enriched treatment.

A clear succession of diatoms was observed during the time course experiment. In both the nutrientenriched treatment and control, Chaetoceros spp. and Skeletonema costatum first showed a marked increase, until the middle of the experiment when these populations collapsed (Fig. 6). Following the peaks of these algae, 3 other diatoms started to increase, Thalassiosira baltica, Cylindrotheca closterium and Fragilaria spp. The same order of succession was observed in the control and nutrient-enriched systems, even though the plankton biovolumes of the different taxonomic groups were about 10 times higher in the nutrientenriched experiments. 


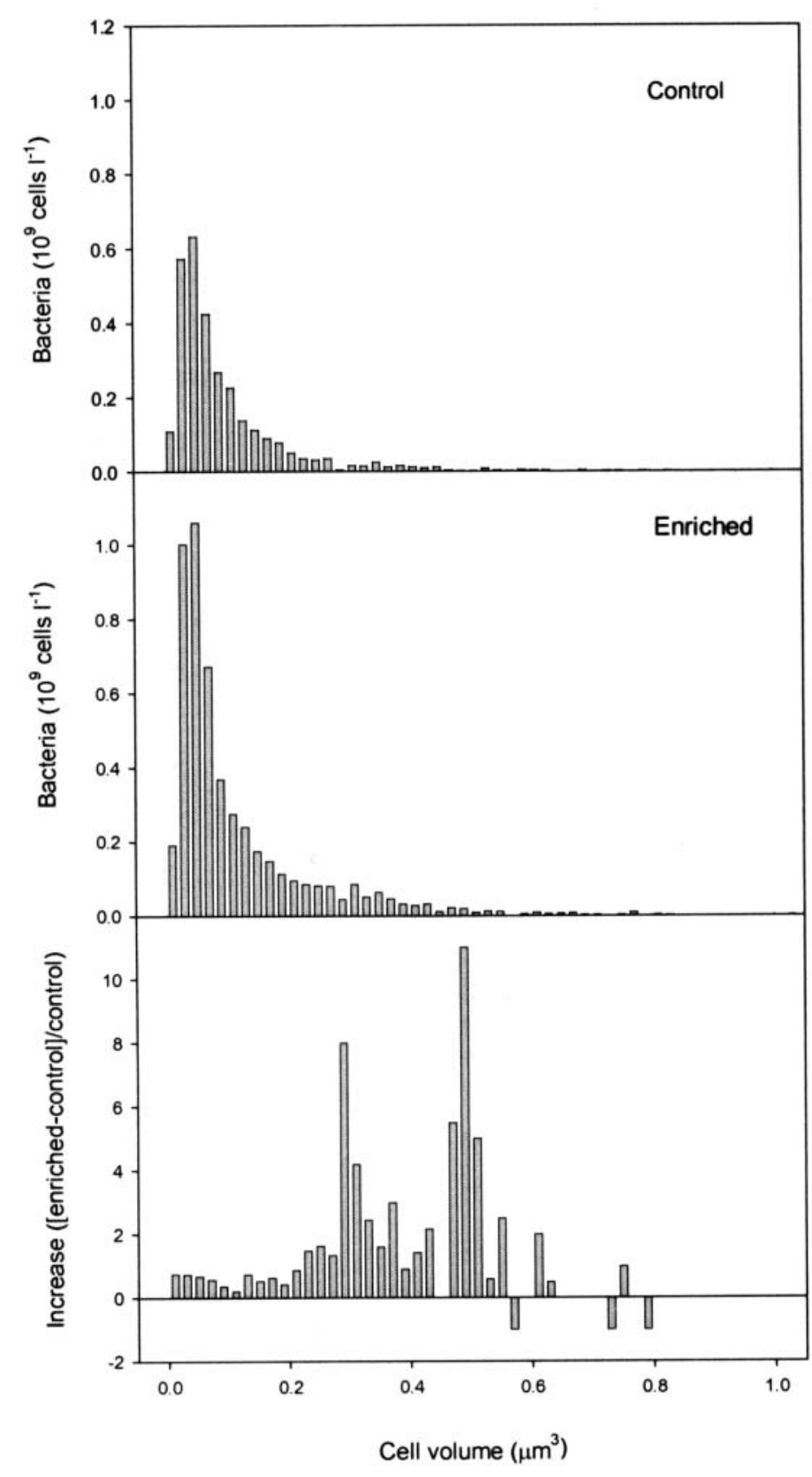

Fig. 5. Distribution of bacterial cell volumes in the nutrientenriched and control treatments. Differences between the nutrient-enriched treatment relative to the control are shown in the lower panel
Table 1. Average biovolume distribution of autotrophic, potentially mixotrophic and heterotrophic flagellates in \% of total flagellate biovolume. Numbers represent averages over the 5 last samplings of the time course experiment, Days 25 to 39 , in the control and nutrient enriched treatments

\begin{tabular}{|c|c|c|c|}
\hline Treatment & $\begin{array}{c}\text { Autotrophic } \\
\text { flagellate } \\
(\%)\end{array}$ & $\begin{array}{c}\text { Potentially } \\
\text { mixotrophic } \\
\text { flagellate } \\
(\%)\end{array}$ & $\begin{array}{c}\text { Heterotrophic } \\
\text { flagellate } \\
(\%)\end{array}$ \\
\hline Control 1 & 2 & 88 & 10 \\
\hline Control 2 & 1 & 88 & 11 \\
\hline Control 3 & 2 & 87 & 11 \\
\hline $\begin{array}{l}\text { Nutrient } \\
\quad \text { enriched } 1\end{array}$ & 9 & 33 & 58 \\
\hline $\begin{array}{l}\text { Nutrient } \\
\quad \text { enriched } 2\end{array}$ & 4 & 42 & 54 \\
\hline $\begin{array}{l}\text { Nutrient } \\
\quad \text { enriched } 3\end{array}$ & 4 & 23 & 73 \\
\hline$t$-test ${ }^{\mathrm{a}}$ & $\mathrm{p}$ & $\mathrm{p}$ & $\mathrm{p}$ \\
\hline Treatment & 0.120 & 0.009 & 0.012 \\
\hline
\end{tabular}

The decrease of plankton abundance in the nutrientenriched systems during the second half of the experiment may have had 2 explanations. Silica deficiency may have been triggered in the nutrient-enriched bottles, since this compound was not added to the incubation flasks. The silicate concentration was observed to be close to zero at the end of the experiment (Table 2). Another possibility was colonisation of microorganisms on the surface of the incubation bottles. The walls of the incubation bottles were mechanically scraped at the end of the experiment to examine wall-attached organisms: filamentous bacteria and pennate diatoms were found. Nutrient data were used to calculate the quantitative importance of this bottle effect. Nutrients were added 11 times and each time $1.6 \mu \mathrm{mol}$ phosphorus $\mathrm{l}^{-1}$ and $5.3 \mu \mathrm{mol}$ nitrogen $\mathrm{l}^{-1}$ were added. Considering the sampling removal of nutrients, the total phosphorus in the water should have increased by 16.2

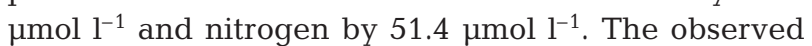
increase of total phosphorus and nitrogen in the water phase constituted 92 and $61 \%$ of the additions, respec-

Table 2. Nutrient concentrations at the start and end of the time course experiment

\begin{tabular}{|c|c|c|c|c|c|c|c|}
\hline Treatment & Time & 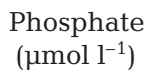 & $\begin{array}{l}\text { Total phosphorus } \\
\left(\mu \mathrm{mol} \mathrm{l} \mathrm{l}^{-1}\right)\end{array}$ & $\begin{array}{c}\text { Ammonium } \\
\left(\mu \mathrm{mol} \mathrm{l}^{-1}\right)\end{array}$ & 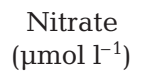 & $\begin{array}{l}\text { Total nitrogen } \\
\left(\mu \mathrm{mol} \mathrm{l}^{-1}\right)\end{array}$ & $\begin{array}{r}\text { Silicate } \\
\left(\mu \mathrm{mol} \mathrm{^{-1 } )}\right.\end{array}$ \\
\hline Control & Start & $<0.01$ & 0.11 & 0.46 & 1.92 & 18.8 & 25.9 \\
\hline $\begin{array}{l}\text { Nutrient } \\
\text { enriched }\end{array}$ & Start & 1.30 & 1.69 & 3.55 & 3.83 & 24.1 & 28.6 \\
\hline Control & End & $<0.01$ & 0.09 & 0.37 & 0.72 & 13.6 & 23.7 \\
\hline $\begin{array}{l}\text { Nutrient } \\
\text { enriched }\end{array}$ & End & 8.61 & 16.5 & 0.68 & 0.06 & 55.7 & 0.76 \\
\hline
\end{tabular}



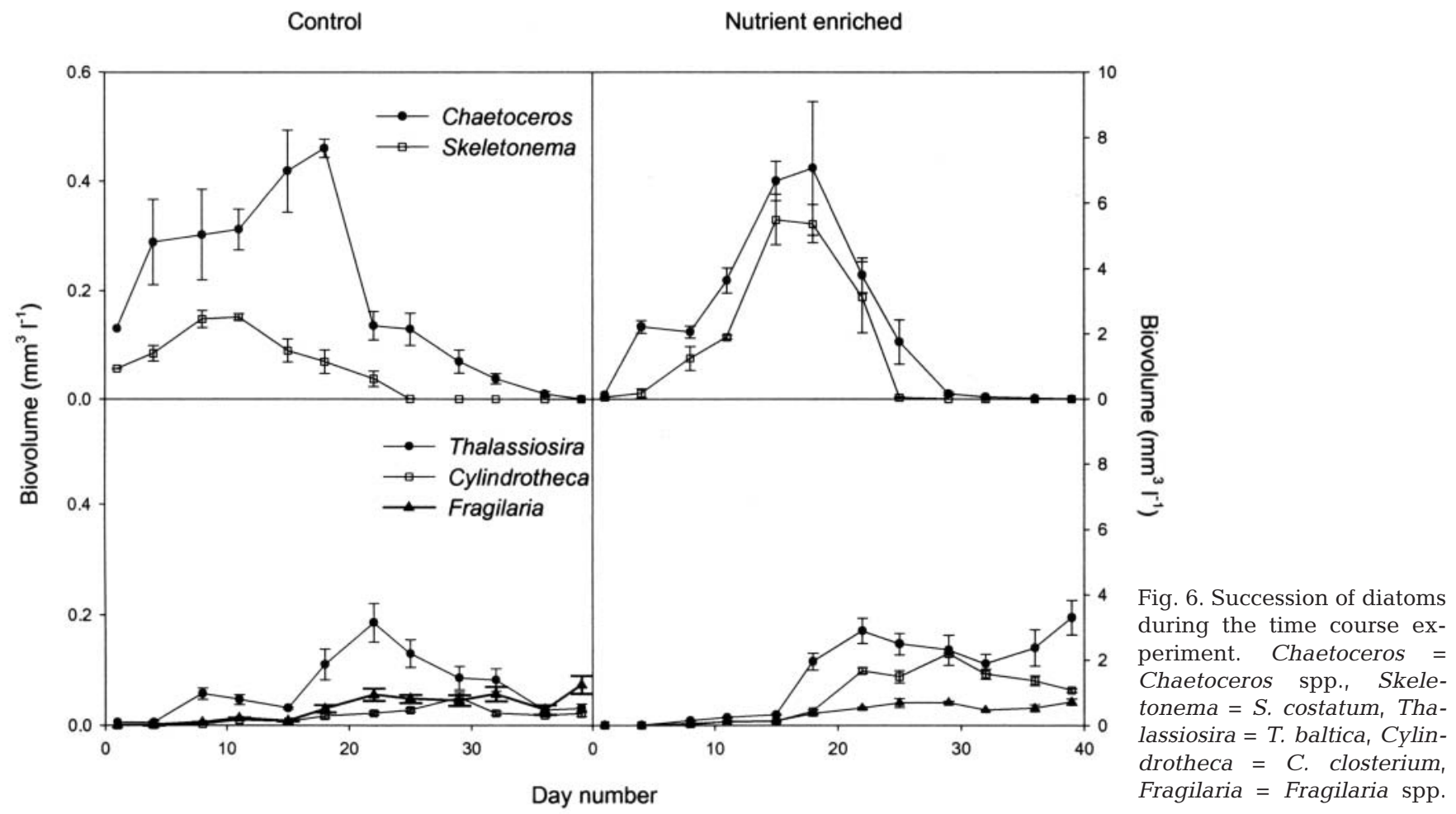

tively. The rest of the added nutrients (8 and $39 \%$ of phosphorus and nitrogen, respectively) must have been attached to the walls of the incubation bottles in the nutrient-enriched treatments. In the control, total phosphorus decreased by $4 \%$ and total nitrogen by $14 \%$ over the time course experiment. The data indicate that approximately 5 to $40 \%$ of the plankton were attached to the walls of the incubation bottles. These figures agree relatively well with the observed decrease of the plankton biovolume over the last part of the experiment (Fig. 1).

All analysed plankton groups increased in numbers when nutrients were added. The relative increase,

Table 3. Average concentrations of different plankton groups in the nutrientenriched $(\mathrm{N})$ and control $(\mathrm{C})$ treatments during the last part of the experiment, Days 25 to 39

\begin{tabular}{|lccc|}
\hline Organism & $\begin{array}{c}\text { Nutrient enriched } \\
\left(\mathrm{mm}^{3} \mathrm{l}^{-1}\right)\end{array}$ & $\begin{array}{c}\text { Control } \\
\left(\mathrm{mm}^{3} \mathrm{l}^{-1}\right)\end{array}$ & $\begin{array}{c}\text { Increase factor } \\
(\mathrm{N} \div \mathrm{C})\end{array}$ \\
\hline Hetrotrophic bacteria & 0.37 & 0.09 & 4 \\
Autotrophic bacteria & 0.44 & 0.14 & 3 \\
Heterotrophic flagellates & 0.60 & 0.01 & 60 \\
Potentially mixotrophic flagellate & 0.34 & 0.07 & 5 \\
Autotrophic flagellate & 0.06 & 0.001 & 60 \\
Ciliates & 1.06 & 0.04 & 26 \\
Chaetoceros spp. & 0.40 & 0.05 & 8 \\
Skeletonema costatum & 0.009 & 0.00006 & 150 \\
Thalassiosira baltica & 2.47 & 0.07 & 35 \\
Cylindrotheca closterium & 1.54 & 0.03 & 51 \\
Fragilaria spp. & 0.62 & 0.05 & 12 \\
\hline
\end{tabular}

\section{DISCUSSION}

In agreement with other enrichment studies, we observed a change in plankton size distribution with differing nutrient status (e.g. Kivi et al. 1996, Duarte et al. 2000). In the nutrient-poor treatment picoplankton dominated, while at high nutrient concentration the microplankton fraction became abundant. Both autotrophic and heterotrophic organisms contributed to this pattern. In the nutrient-rich treatment diatoms as well as ciliates became abundant. The changing size distribution may, for the osmotrophic organisms, be explained by different nutrient 
uptake properties (Legendre \& Rassoulzadegan 1995). The biovolume-specific uptake of nutrients by bacteria was probably larger than that by diatoms in the nutrient-poor control, while the opposite situation was likely in the nutrient-enriched treatment. This presumably led to a dominance of bacteria in the control and diatoms in the nutrient-enriched treatments, respectively.

A recent study has shown that higher productivity can lengthen experimental microbial food chains (Kaunzinger \& Morin 1998). In natural environments eutrophication often leads to blooms of inedible or toxic phytoplankton species, which are not entering the food chain and may be harmful to other organisms (Hansen et al. 1995, Engström et al. 2001). In this enrichment experiment we used a natural aquatic community, which might harbour potentially toxic or inedible species. We did not, however, find any shift towards potentially toxic algae with nutrient enrichment. Neither did we find any change towards dominance of filamentous inedible bacteria, which is often observed in systems with high flagellate grazing pressure on bacteria (e.g. Hahn \& Höfle 1999, Jürgens \& Montserrat Sala 2000). The reason why we did not obtain such a shift in the bacterial community could be that grazing on bacteria was reduced by the predation on flagellates by ciliates. However, an increase of relatively large bacterial cells was observed. It could not be determined whether these bacteria were predation resistant or just had a higher growth rate than smaller bacteria. The relatively large bacteria did not seem to have any hindering effect on the prolongation of the food web, since ciliates increased considerably in the nutrient-enriched treatment.

In this study no direct measurement of mixotrophy was performed. In the southern Baltic Sea, Havskum \& Rieman (1996) studied the uptake of fluorescently labelled bacteria (FLB) by mixotrophic flagellates. They found 2 Chrysochromulina species $<5 \mu \mathrm{m}, C$. brachycylindra and C. minor, which showed significant uptake of FLB, and thus were mixotrophic. In the present study, mixotrophy of Chrysochromulina species was indicated by their high concentration in the control compared to autotrophic and heterotrophic flagellates, and by their low increase after nutrient addition compared to heterotrophic and autotrophic flagellates (Table 3). One reason for this could be that mixotrophic nanoflagellates are generalists, which have a competitive advantage in nutrient-poor conditions relative to the more specialised heterotrophic and autotrophic flagellates (e.g. Andersson et al. 1989, Nygaard \& Tobiesen 1993). Havskum \& Hansen (1997) showed that mixotrophic dinoflagellates in enclosure experiments were more important under nutrient-poor conditions. In the nutrient-enriched enclosures, het- erotrophic flagellates and ciliates became more important. In marine enclosures, both in the southern Baltic Sea and in the Mediterranean Sea, mixotrophic flagellates were most important in nutrient limited treatments, while addition of nutrients mainly favoured growth of heterotrophic and autotrophic forms (Baretta-Bekker et al. 1998, Christaki et al. 1999).

Unmanipulated field studies also show that the proportion of mixotrophic flagellates in the total phytoplankton community is highest under nutrient-poor conditions. In the northern Baltic proper, the potentially mixotrophic Chrysochromulina species showed abundance maxima after long periods of low levels of inorganic phosphorus (Hajdu et al. 1996). From a study performed in the northern Baltic Sea it can be calculated that Chrysochromulina constituted $34 \%$ of the total autotrophic biomass in late summer when the nutrient concentrations were low (Andersson et al. 1996). During the nutrient-rich spring bloom Chrysochromulina only constituted $1 \%$ of the phytoplankton. In the southern Baltic Sea mixotrophic flagellates accounted for $49 \%$ of the total pigmented biomass in the nutrient-depleted surface water, but only $9 \%$ in the nutrient-rich deeper water layer (Havskum \& Rieman 1996). In the present study Chrysochromulina accounted for $21 \%$ of the autotrophic biovolume in the nutrient-poor control experiment, and for only $2 \%$ in the nutrient-enriched experiments. The values cannot be compared directly between the studies, because in this study we estimated biovolume and in the other studies, carbon biomass was presented. However, it can be concluded that the trend was the same in the present study, that the potentially mixotrophic Chrysochromulina sp. were more important under nutrient-poor conditions.

The abundance of organisms in any environment depends not only on substrate limitation, but also on other factors like predation limitation. In our experimental system, diatoms, specialised autotrophic and heterotrophic flagellates and ciliates showed relatively large increases with nutrient enrichment (Table 3). It may be argued that this was partly due to the absence of larger grazers. In natural aquatic environments higher trophic levels, like mesozooplankton, may affect the microbial food web and size structure of phytoplankton (Kivi et al. 1996). A mesocosm study performed in the Baltic Sea during the spring bloom, however, showed that removal of larger grazers $(>100 \mu \mathrm{m})$ had no effect on the phytoplankton dynamics (Kuosa et al. 1997). In some respects our nutrientenriched system resembled a spring bloom. The temperature was relatively low and diatoms dominated the phytoplankton community. The major loss process of spring bloom algae seems to be sedimentation (Riebesell 1989, Kiørboe et al. 1994, Tiselius \& Kuylenstierna 
1996). Furthermore, in a mesocosm study performed in the Mediterranean Sea, in which zooplankton were not excluded, nutrient enrichments resulted in similar increases in the proportion of microplankton as in our study (Duarte et al. 2000). We therefore propose that the main results of this study are valid in natural aquatic environments receiving increased nutrient loads.

All 5 diatoms that dominated in the experiment are spring bloom species, which show peaks from April through May in the Gulf of Bothnia (Andersson et al. unpubl. data). Normally Chaetoceros and Thalassiosira are more important than Skeletonema, Cylindrotheca and Fragilaria in the coastal area where the experimental seawater was collected. During the experiment the diatoms showed a clear succession. Chaetoceros wighamii and Skeletonema costatum dominated during the first half of the experiment, after which their biovolume decreased. During the decline of these algae Thalassiosira baltica, Cylindrotheca closterium and Fragilaria spp. increased in biovolume. In the Gulf of Bothnia all the mentioned diatoms often show peaks at the same time during the spring bloom. T. baltica and Fragilaria spp., however, have secondary peaks later during the productive season, indicating that these species are late successional forms. It is likely that wall-growing pennate forms were promoted since the bottle experiment lasted a relatively long time. This might explain the late dominance by Fragilaria spp. and C. closterium but not the late dominance of the centric diatom $T$. baltica. Since the succession of diatoms was similar in the nutrient-poor control and the nutrient-enriched treatment, we find it likely that not only the nutrient regime governed the diatom succession. In the control, phosphorus limitation prevailed and in the nutrient-enriched treatment silica limitation prevailed. The fact that diatoms showed strong dominance in both treatments is probably because of the high initial inorganic Si:N molar ratios, 11 and 4 in the control and nutrient-enriched treatments, respectively. It is believed that diatoms need a Si:N molar ratio of 1:1 for growth (e.g. Harris 1986), but that they are favoured over other algae when this ratio is $>25: 1$ (Sommer 1994). In our experiment the atomic ratios of silica and nitrogen were not that high, but nevertheless diatoms were promoted in front of cryptophyceans, prymnesiophyceans and green algae.

In conclusion, the results indicate an extension of the microbial food web with nutrient enrichment, since the top predators (oligotrich ciliates) became firmly established in the enriched treatment, while they were close to exclusion in the control. Prolongation of the food web length was thus not hindered by predationresistant species. A potentially mixotrophic species,
Chrysochromulina sp., dominated the flagellate community in the nutrient-poor treatment, but coexisted with specialised heterotrophs and autotrophs in the nutrient-enriched treatment. Furthermore, pico- and nanoplankton dominated in the control and microplankton in the nutrient-enriched treatment. We find it likely that the general results of this study are also true for natural aquatic environments with larger predators present.

Acknowledgements. This work was supported by grants from Umeå Marine Sciences Centre. We thank Erik Lundberg and Carl-Henrik Stangenberg for chemical analyses.

\section{LITERATURE CITED}

Andersson A, Falk S, Samuelsson G, Hagström ^̊ (1989) Nutritional characteristics of a mixotrophic nanoflagellate, Ochromonas sp. Microb Ecol 17:251-262

Andersson A, Haecky P, Hagström Å (1994) Effect of temperature and light on the growth of micro-, nano- and picoplankton: impact on algal succession. Mar Biol 120: 511-520

Andersson A, Hajdu S, Haecky P, Kuparinen J, Wikner J (1996) Succession and growth limitation of phytoplankton in the Gulf of Bothnia (Baltic Sea). Mar Biol 126:791-801

Balciunas D, Lawler SP (1995) Effects of basal resources, predation, and alternative prey in microcosm food chains. Ecology 76:1327-1336

Baretta-Bekker JG, Baretta JW, Hansen AS, Rieman B (1998) An improved model of carbon and nutrient dynamics in the microbial food web in marine enclosures. Aquat Microb Ecol 14:91-108

Blackburn N, Hagström $\AA$, Wikner J, Cuadros-Hansson R, Koefoed Bjørnsen P (1998) Rapid determination of bacterial abundance, biovolume, morphology and growth by network-based image analysis. Appl Environ Microbiol 64:3246-3255

Brett MT, Goldman CR (1997) Consumer versus resource control in freshwater pelagic food webs. Science 275:384-386

Christaki U, Van Wambeke F, Dolan JR (1999) Nanoflagellates (mixotrophs, heterotrophs and autotrophs) in the oligotrophic eastern Mediterranean: standing stocks, bacterivory and relationships with bacterial production. Mar Ecol Prog Ser 181:297-307

Duarte CM, Agustí S, Agawin NSR (2000) Response of a Mediterranean phytoplankton community to increased nutrient inputs: a mesocosm study. Mar Ecol Prog Ser 195: $61-70$

Engström J, Viherluoto M, Viitasalo M (2001) Effects of toxic and non-toxic cyanobacteria on grazing, zooplanktivory and survival of mysid shrimp Mysis mixta. J Exp Mar Biol Ecol 257:269-280

Gifford DJ (1985) Laboratory culture of marine planktonic oligotrichs (Ciliophora, Oligotrichida). Mar Ecol Prog Ser 23:257-267

Grasshof KM, Ehrhardt M, Kremling K (1983) Methods of seawater analysis, 2nd edn. Verlag Chemie, Weinheim

Hahn MW, Höfle MG (1999) Flagellate predation on a bacterial model community: interplay of size-selective grazing, specific bacterial cell size, and bacterial community composition. Appl Environ Microbiol 65:4863-4872

Hajdu S, Larsson U, Moestrup Ö (1996) Seasonal variation of Chrysochromulina species (Prymnesiophyeae) in a coastal 
area and nutrient-enriched inlet of the northern Baltic proper. Bot Mar 39:281-295

Hansen PJ, Nielsen TG, Kaas H (1995) Distribution and growth of protists and mesozooplankton during a bloom of Chrysochromulina spp. (Prymnesiophyceae, Prymnesiales). Phycologia 34:409-416

Harris GP (1986) Phytoplankton ecology. Structure, function and fluctuation. Chapman and Hall, London

Havskum H, Hansen AS (1997) Importance of pigmented and colourless nano-sized protists as grazers on nanoplankton in a phosphate-depleted Norwegian fjord and in enclosures. Aquat Microb Ecol 12:139-151

Havskum H, Rieman B (1996) The ecological importance of bacterivorous pigmented flagellates (mixotrophs) in the Bay of Århus. Mar Ecol Prog Ser 137:251-263

Jürgens K, Montserrat Sala M (2000) Predation-mediated shifts in size distribution of microbial biomass and activity during detritus decomposition. Oikos 91:29-40

Kaunzinger CMK, Morin PJ (1998) Productivity controls foodchain properties in microbial communities. Nature 395: 495-497

Kiørboe T, Lundsgaard C, Olesen M, Hansen JLS (1994) Aggregation and sedimentation processes during a spring phytoplankton bloom - a field experiment to test coagulation theory. J Mar Res 52:297-323

Kivi K, Kuosa H, Tanskanen S (1996) An experimental study on the role of crustacean and microprotozoan grazers in the planktonic food web. Mar Ecol Prog Ser 136:59-68

Editorial responsibility: Robert Sanders, Philadelphia, Pennsylvania, USA
Kuosa H, Autio R, Kuupo P, Setälä O, Tanskanen S (1997) Nitrogen, silicon and zooplankton controlling the Baltic spring bloom: an experimental study. Estuar Coast Shelf Sci 45:813-821

Legendre L, Rassoulzadegan F (1995) Plankton and nutrient dynaimcs in marine waters. Ophelia 41:153-172

Nygaard K, Tobiesen A (1993) Bacterivory in algae: a survival strategy during nutrient limitation. Limnol Oceanogr 38: 273-279

Riebesell U (1989) Comparison of sinking rate and sedimentation rate measurements in a diatom winter/spring bloom. Mar Ecol Prog Ser 54:109-119

Rothhaupt KO (1996) Laboratory experiments with a mixotrophic chrysophyte and obligate phagotrophic and phototrophic competitors. Ecology 77:716-724

Sanders RW (1991) Mixotrophic protists in marine and freshwater ecosystems. J Protozool 38:76-81

Sommer U (1994) Are marine diatoms favoured by high Si:N ratios? Mar Ecol Prog Ser 115:309-315

Thingstad TF, Sakshaug E (1990) Control of phytoplankton growth in nutrient recycling ecosystems. Theory and terminology. Mar Ecol Prog Ser 63:261-272

Tiselius P, Kuylenstierna M (1996) Growth and decline of a diatom spring bloom: phytoplankton species composition, formation of marine snow and the role of heterotrophic dinoflagellates. J Plankton Res 18:133-155

Vanni MJ (1987) Effects of food availability and fish predation on zooplankton community. Ecol Monogr 57(1):61-88

Submitted: January 28, 2002; Accepted: June 1, 2002 Proofs received from author(s): August 7, 2002 